\title{
Identifying Teacher Expertise: An Examination of Researchers' Decision Making
}

\author{
Douglas J. Palmer and Laura M. Stough \\ Department of Educational Psychology \\ Texas A\&M University \\ Thomas K. Burdenski, Jr. \\ Department of Psychology \\ Adams State College \\ Maricela Gonzales \\ Department of Educational Psychology \\ Texas A\&M University
}

\begin{abstract}
This article reviews indicators used by researchers to select samples of expert teachers. Reflecting initially on the broader expertise literature and then focusing on studies of teaching expertise, the authors identify criteria used to select expert teachers that fall under one or more of the following marker categories: (a) years of experience, (b) social recognition, (c) professional or social group membership, and (d) performance based criteria (including normative and criterion-based selection). Results indicate considerable variability in the selection criteria for identifying expert teachers, even among researchers using the same theoretical construct. Based on this review, a rubric for selecting samples of expert teachers is proposed.
\end{abstract}

Currently, the field of education is strongly influenced by a national movement that emphasizes high-stakes student testing, holding teachers and schools almost exclusively accountable for the achievement outcomes of their students (e.g., No Child Left Behind Act P. L. 107-110, 2002). One of the outcomes of these reform efforts has been an increased focus on teacher quality and on the evaluation of teachers (Dwyer \& Stufflebeam, 1996). Recent national reports have concluded that the most important resource that a community can provide to foster children's success at learning is the quality of the teacher (The American Council on Education, 1999; National Commission on Teaching and America's Future, 2003). Reflecting on the importance of teacher quality, the No Child Left Behind Act established a standard that by the 2005-2006 school year all students would be taught by "highly qualified" teachers in the core academic subjects. What determines teacher quality, however, has been an evolving concept, not only for policy-makers (Education Trust, 2003), but for researchers.

Requests for reprints should be sent to Douglas J. Palmer, Department of Educational Psychology, Texas A\&M University, MS 4225, College Station, TX 77843-4225. E-mail: dpalmer@tamu.edu
Process-product research during the 1970s and 1980s addressed the issue of teacher quality primarily by studying the impact of specific teacher behaviors on student performance (see Brophy \& Good, 1986; Doyle, 1986). A subsequent wave of research on teacher effectiveness emphasized how teacher cognition and decision-making affected the quality of classroom instruction (Calderhead, 1996). In the last 20 years, educational researchers have explored the construct of teacher expertise, which has its theoretical roots in cognitive psychology (e.g., Berliner, 1994; Carter, Sabers, Cushing, Pinnegar, \& Berliner, 1987; Leinhardt \& Greeno, 1986; Peterson \& Comeaux, 1987). This research has identified a variety of characteristics and practices of effective teachers. In contrast to research focusing on specific instructional interventions used by teachers to improve student performance (e.g., Gersten, Fuchs, Williams, \& Baker, 2001) studies on expertise highlight the complex and dynamic cognitive processing that underlies the instructional decisions made by classroom teachers (see Berliner, 1994).

Little attention has been given to the consistency of the selection criteria used to identify "expert teachers" across studies despite the widespread use of the term "expert teacher." 
Berliner $(1986,1994)$ has explicated clear guidelines for the selection of expert teachers and, quite often, researchers cite Berliner in their descriptions of how they selected their samples. However, a closer examination of these selection procedures reveals considerable variation in how these guidelines are interpreted and implemented by researchers. Sternberg (1998) points out that researchers similarly use the term "gifted teacher" without reflecting on the nature of this terminology, which further obscures the definition of an "expert teacher."

The purpose of this article is to conduct a comprehensive review of investigations on expert teachers and to identify types of markers used by researchers to select these teachers. A number of methodological and conceptual concerns led to our interest in conducting this review. Nunnally and Bernstein (1994) argue that two central concerns of science are (a) developing measures of constructs and (b) identifying relationships between measures of different constructs. Validation of constructs thus requires specification of the domain observables related to the construct (Nunnally \& Bernstein, 1994). Bell and Hertz (1976) have defined marker variables as measures used in a defined research area that facilitates general alignment of findings across studies. Without the identification and consistent application of markers when selecting a sample, it is unclear what, or, in the case of expert teachers, who, is being studied across studies. An inconsistent usage of identification markers thus has significant implications for the generalizability and utility of findings from these studies. If there are differences in how expert teachers are identified, the resultant research literature may be limited in informing educational researchers and policymakers about the nature and development of "highly qualified" teachers. For example, Study A compares instructional cognitions and interactions of student teachers with that of identified "expert" teachers that have three years of teaching experience. In contrast Study B identifies experts by using a variety of dimensions, including years of teaching, and then compares the performance of these identified teachers with expert teachers. Although both studies reportedly involve the study of expert teachers, the nature of the populations studied may be, in actuality, very different. Study A's experts may function as "advanced beginners" (see Berliner, 1994) although they are identified as experts. Any conclusions regarding instructional practices of these "experts" would be suspect due to the variation in the comparison groups. Our review of the research on expert teachers examines procedures used to identify samples of "expert teachers" and clusters these identification markers based on a review of the cognitive concept of expertise. Our summarization provides insight into the methodological decision-making of researchers in this area and is examined in light of related literature on teacher effectiveness.

In addition to methodological issues, there are a number of conceptual concerns that underlie the need for an analysis of the identification of expert teachers. Current licensing standards for teachers have been identified as a barrier to the provision of quality teaching (National Commission on Teaching and America's Future, 2003). With national attention on issues of teacher quality, research on teacher expertise has the potential to influence initiatives in the areas of teacher preparation, assessment, and certification. For example, The National Board for Professional Teaching Standards has reflected directly on the teacher expertise research literature in the development of teaching standards (Bond, Smith, Baker, \& Hattie, 2000).

Policymakers have proposed that skill sets for qualified teachers are generalizable across student characteristics and instructional content, for example, teachers with elementary certification are prepared to teach students in multiple subject areas from kindergarten through sixth grade. In contrast, research reviews in teacher expertise have reported that expertise is context and task specific suggesting that one should be cautious in generalizing teachers' performance across grade levels and subjects (Berliner, 1994). In a related area, researchers have indicated that subject knowledge is necessary for teachers to be successful (Allen, 2003; Shulman, 1987); however, how much subject knowledge is needed to be successful and how to best assess this knowledge is not clear. Further, Berliner (1994) contends that teachers' knowledge of their students and instructional processes differentiates expert from novice teachers. Stough and Palmer (2003) similarly report that expert special education teachers have a complex body of knowledge and skills, including student-specific knowledge. Moreover, these teachers used their knowledge flexibly in order to address the unique needs of their students. However, the import of these various domains of knowledge in identifying expert teachers is also unclear.

A review of identification markers in research on teacher expertise will assist researchers' critique of extant expertise literature and in their design of subsequent studies in this area. Since most educational researchers operate independently, they often do not investigate specific constructs as part of an orchestrated research plan; there is seldom an organized effort to develop valid measures of constructs (Nunnally \& Bernstein, 1994). Nunnally and Bernstein note that, instead of researchers defining the domain of observables for a construct, the nature of the domain is derived from numerous and divergent attempts to develop measure of the construct. We propose that our review clarifies those domain observables associated with the construct of teacher expertise.

\section{THE CONSTRUCT OF EXPERTISE}

The seminal studies on teacher expertise (e.g., Borko \& Livingston, 1989; Carter, Sabers, Cushing, Pinnegar, \& Berliner, 1987; Leinhardt, 1983; Peterson \& Comeaux, 1987) have built upon a larger body of research on the cognitive construct of expertise. Studies on expertise in domains other than teaching report that experts think and behave qualitatively different as compared to novices. Investigations using 
this construct have found that individual expertise is unique to a specific domain of activity and requires thousands of hours of dedicated practice within that domain (Berliner, 1994; Ericsson, 1996). Researchers also report that expert knowledge is structured differently than the knowledge of novices; experts are able to access their knowledge in an efficient, fluid manner in order to address novel problems (Berliner, 1994; Glaser \& Chi, 1988). The cognitive characteristics of experts are manifested across a broad range of domains including chess, physics, medicine, and sports (Ericsson, 1996). In sum, cognitive characteristics of expertise have been found to be "consistent and reliable" (Alexander, 2003, p. 3).

Cognitive researchers have used a variety of decision rules, both implicit and explicit, to select and describe experts outside of the domain of teaching. These selection processes merit a review when reflecting upon what decision rules educational researchers currently implement in determining expertise in teachers.

\section{Experience and Deliberate Practice}

The most common indicator associated with the development of expertise has been that of experience, usually defined as years of experience. Simon and Chase (1973) in their study of chess masters, found that a minimum of 10 years of preparation was necessary for individuals to obtain a level of chess skill associated with international competition. Ericsson, Krampe, and Tesch-Romer(1993) argued that it is not only experience, rather it is deliberate practice in a particular domain, that is critical for the development of expertise. Deliberate practice is defined as engagement in tasks that are at an appropriate level of difficulty and that provide the individual with multiple opportunities for the repetition of the tasks, as well as informative feedback on the performance of these tasks so that errors may be corrected (Ericsson et al., 1993).

A characteristic closely associated with deliberate practice of experts is the desire for mastery that experts exhibit within their domain. Starkes, Deakin, Allard, Hodges, and Hayes (1996) reported in their study of athletic expertise that both ice skaters and their coaches identified motivation as one of the top characteristics associated with success in skating. Moreover, their interviews with coaches indicated that the highest performing athletes were those individuals who not only had the will to win but had the "will to prepare to win" as a critical defining characteristic. Experts thus appear to seek out opportunities for deliberate practice and mastery within their domain.

Similarly, Sternberg's (1998) model of developing expertise emphasizes that individuals develop expertise when they actively work in a specific domain. Although there are individual differences in the speed of acquisition and level of expertise attained, Sternberg argues that the primary determinant in achieving expertise is purposeful engagement of the individual in the practice of their expertise. This engagement is characterized by both direct instruction and extensive reflective practice by the individual who is motivated to acquire the expertise.

\section{Social Recognition of Expertise and Social Group Membership}

Agnew, Ford, and Hayes (1997) have argued that human expertise is, in part, a social attribution. Specifically, they note

What do snake oil salesmen, TV evangelists, chicken sexers, small motor mechanics, geologists, radiologists, and computer scientists all have in common? They all meet the minimum criterion for expertise, namely they all have a constituency that perceives them to be experts. (p. 219)

Likewise, LaFrance (1997) has proposed a set of metaphors for expertise that includes the metaphor term "courtship," that is, experts are chosen and described by others as "experts." Individuals selected as experts may not be the most knowledgeable but they are selected as experts because others consider them to be experts. One form of social recognition of expertise is membership in a group that has been certified or professionally recognized as possessing expertise. For example, Patel, Kaufman, and Magder (1996) report that medical experts are usually identified by a physician's board certification in a specialty area and by social recognition that this is an area of specialized expertise. Similarly, expertise in physics has been defined through membership in a group, such as physics graduate students or those who have obtained degrees in physics (Chi, Feltovich, \& Glaser, 1981).

Agnew et al. (1997) propose two levels of expertise. All experts are socially selected by a constituency (Level 1). Level 1 experts may also be involved in selecting colleagues to join their ranks, for example, professional licensing boards in medicine and law, resulting in consensually validated expertise. In addition, Agnew et al., propose there is also a "reality-relevant" Level 2 expertise. Level 2 experts achieve their status as a result of verifiable, empirical performance indicators that have met stringent scientific standards. Both normative and criterion performance indicators have been used to identify expertise.

\section{Normative Performance Indicators}

The study of expertise, in part, is an examination of the performance of those who perform better than the average in some domain of human activity. Individuals who consistently win in competitions against opponents are considered experts (Ericsson, 1996). For example, chess players identified as Grand Masters by the U. S. Chess Federation have acquired a specified number of points on the Elo (1986) scale, which is a scale derived from outcomes of competitions between players (see Charness, Krampe, \& Mayr, 1996). Normative performance indicators are definitionally linked to so- 
cial recognition indicators as both the nature of the performance criteria and the comparison groups are determined from a social selection process (Agnew, et al., 1997).

\section{Criterion-Based Performance Indicators}

Outstanding performance also can be defined in absolute terms, in that it reflects the quantity or quality of performance, or it can be based on a criterion-based scale (Ericsson, 1996; Sloboda, 1996; Winner, 1996). Criterion-based performance measures may include the frequency, the accuracy, or the duration with which a task is performed. Sloboda (1996) reported that expert musicians' performance characteristics reflect identifiable elements of fluency, accuracy, and speed. However, Sloboda also noted that these musicians additionally display unique, expressive performance characteristics - qualities that require subjective evaluation of performance. This perspective is also reflected by Winner (1996), who notes that experts in the visual arts are not only skilled but invent new ways of thinking, seeing, and problem solving that are qualitatively different from nonexperts.

The following is a review of studies that have identified "expert teachers" as their subjects. We have chosen to focus on those studies that referred directly to the cognitive construct of expertise in order to ensure a common theoretical thread across all the studies that we review here. We identify those criteria most commonly used by investigators to identify teacher expertise and examine identification markers used across studies. Reflecting on these methodologies, along with related literature on expertise and teacher effectiveness, we make recommendations for identification of the "expert" teacher in future studies.

\section{METHOD}

There were two components to this study: (a) the identification of the population of studies on teacher expertise and (b) the categorization of the selection criteria used to identify expert teachers.

\section{Identification of Research Studies}

We engaged in a multistage process to identify studies for inclusion. The first stage involved a search of electronic databases including ERIC, Education Abstracts, and Ovid Psychinfo. The ERIC (1966-1999) database was searched using the following key phrases: "novice teacher," "expert teacher," "novice and expert," and "beginning teacher." Additional ERIC and Education Abstracts searches were then conducted using the subjects "expert," "expertise," and "teacher" for the years 1995 to 2000 to ensure that relevant articles had not been missed. We also conducted an Ovid PsycInfo search (1967-1999) using the key phrases "reflective teaching," "teacher reflection," "novice," "expert," "ex- pert teacher education," "novice and teacher," "teacher training," "expert teachers," and "expert and teacher." We followed these searches with another PsycInfo search using the following descriptors: "expert cognitive processes," "expert competence," "expert knowledge level," "expert competence," "teacher or educator," "teacher and educator," "performance assessment," and "professional expertise." Eight months after the first electronic search was completed, a final ERIC electronic search was conducted using the following descriptors: "expert teachers," "expert," and "teaching." These searches together generated 258 references.

From this pool, redundant references were dropped and only those papers published in peer-reviewed English language journals that contained original research data were retained. Authors individually reviewed each of these papers for inclusion. Since the researchers were primarily interested in identifying markers for expert teachers of school-aged children (kindergarten to 12th grade), we limited the studies to this population.

Although our searches had resulted in a large number of articles that referred to teacher expertise, we found that many of these studies used the term "expertise" but not the cognitive construct as has been described and developed by cognitive scientists (e.g., Glaser \& Chi, 1988; Simon \& Chase, 1973 ) or educational researchers such as Berliner (1986), Leinhardt (1983) and Livingston and Borko (1990). In other studies, the teaching expertise literature was reviewed in the introduction but the researchers chose to use terms such as "experienced" teacher (e.g., Housner \& Griffey, 1985) rather than "expert" teacher. Thus, to ensure that studies focused on the cognitive construct of expertise, we limited our sample to those studies that both used the construct of teaching expertise and explicitly labeled the teachers within their study as "experts."

We also found that some researchers (e.g., Borko \& Livingston, 1989; Livingston \& Borko, 1989, 1990) used either the same sample or a subset of the same sample in more than one study. In these cases, either the earliest study or the study with the most explicit description of the sample selection process was included in the group of selected articles. We subsequently conducted a final review of the reference lists of the remaining studies to locate additional relevant studies. Following these procedures, 27 studies were identified and are listed in Table 1.

\section{Categorization of Selection Criteria}

Our review of research on the construct of "expertise" across disciplines revealed a number of markers used to identify experts. This review provided guidance in initial decision-making in the identification and selection of expert teachers. We then engaged in an iterative process in which we individually reviewed a sample of 12 articles with identified "expert" teachers and then met to discuss criteria used in these studies. From this sample, several initial categories of selection crite- 
TABLE 1

Identification Markers for Research Samples of Expert Teachers

\begin{tabular}{|c|c|c|c|c|}
\hline \multirow[b]{2}{*}{ Study } & \multicolumn{4}{|c|}{ Identification Markers } \\
\hline & Years of Experience & $\begin{array}{c}\text { Social } \\
\text { Recognition/Nomination }\end{array}$ & $\begin{array}{l}\text { Professional/Social } \\
\text { Group Membership }\end{array}$ & $\begin{array}{l}\text { Performance Criteria }(N=\text { Normative, } \\
\qquad=\text { Criterion Based })\end{array}$ \\
\hline $\begin{array}{l}\text { Allen \& Casbergue } \\
\text { (1997) }\end{array}$ & (2) $10+$ & $\begin{array}{l}\text { (2) Nomination by } \\
\text { principal }\end{array}$ & $\begin{array}{l}\text { (1) Cooperating } \\
\text { teacher with local } \\
\text { university }\end{array}$ & \\
\hline $\begin{array}{l}\text { Bartelheim \& Evans } \\
\text { (1993) }\end{array}$ & $\begin{array}{l}\text { (2) } 5+\text { in resource } \\
\text { room }\end{array}$ & $\begin{array}{l}\text { (1) School principal and } \\
\text { district special } \\
\text { education office }\end{array}$ & $\begin{array}{l}\text { (2) Certified as } \\
\text { resource special } \\
\text { education teacher }\end{array}$ & \\
\hline $\begin{array}{l}\text { Bromme \& } \\
\quad \text { Steinbring (1994) }\end{array}$ & & & & $\begin{array}{l}\text { (1) } \mathrm{N}=\text { One expert teacher was chosen from a sample of } \\
26 \text { math teachers on the basis of classroom observations } \\
\text { measuring instructional quality: (a) student engagement } \\
\text { (by recording number of off-task student behaviors), (b) } \\
\text { control of instructional flow, (c) clarity of teacher } \\
\text { statements, (d) clarity of blackboard and overhead } \\
\text { presentations, (e) teacher's enthusiasm,(f) teacher's } \\
\text { "with-it-ness" }\end{array}$ \\
\hline $\begin{array}{l}\text { Bullough \& } \\
\text { Baughman } \\
\text { (1995)* }\end{array}$ & (1) 6 & & & $\begin{array}{l}\text { (2) Authors state that case study teacher exhibited many } \\
\text { of the qualities outlined in Berliner (1988) }\end{array}$ \\
\hline $\begin{array}{l}\text { Carter, Sabers, } \\
\text { Cushing, Pinnegar, } \\
\text { \& Berliner (1987)* }\end{array}$ & (3) $5+$ & $\begin{array}{l}\text { (1) School } \\
\text { superintendent and/or } \\
\text { principals }\end{array}$ & & $\begin{array}{l}\text { (2) } \mathrm{N}=18 \text { experts were selected out of the nominated } \\
\text { group of } 54 \text { by project personnel, all of whom were } \\
\text { knowledgeable about research on teaching and who } \\
\text { either had classroom teaching experience or were } \\
\text { trained in classroom observation techniques. Each } \\
\text { nominated teacher was observed by three or more } \\
\text { researchers, who selected those teachers whose } \\
\text { teaching performance "set them apart" from their peers. } \\
\text { If experts were not unanimous in their rating, teacher } \\
\text { was not selected. }\end{array}$ \\
\hline $\begin{array}{l}\text { Cleary \& Groer } \\
\text { (1994) }\end{array}$ & & $\begin{array}{l}\text { (1) Identified by } \\
\text { principals in their } \\
\text { building and by } \\
\text { personnel from the } \\
\text { university skilled in } \\
\text { methods of } \\
\text { observation }\end{array}$ & $\begin{array}{l}\text { (2) Cooperating } \\
\text { teacher }\end{array}$ & \\
\hline $\begin{array}{l}\text { Copeland, } \\
\text { Birmingham, } \\
\text { DeMeulle, } \\
\text { D'Emidio-Caston, } \\
\text { \& Natal (1994) }\end{array}$ & $\begin{array}{l}\text { (1) "Extensive } \\
\text { experience in } \\
\text { elementary } \\
\text { teaching" }(M= \\
20 \text { years, } S D= \\
4.6)\end{array}$ & & $\begin{array}{l}\text { (2) Selected } \\
\text { consistently to } \\
\text { serve as } \\
\text { cooperating } \\
\text { teachers }\end{array}$ & $\begin{array}{l}\text { (1) } C=\text { "Taught at least three different grade levels." } \\
\text { (2) } C=\text { "Were the only Cooperating Teachers } \\
\text { independently rated as Superior Teachers, the highest } \\
\text { rating possible, by } 3 \text { different UCSB student teaching } \\
\text { supervisors." }\end{array}$ \\
\hline $\begin{array}{l}\text { Ethell \& } \\
\text { McMeniman } \\
\text { (2000) }\end{array}$ & & $\begin{array}{l}\text { (1) "An experienced } \\
\text { secondary school } \\
\text { teacher was nominated } \\
\text { by teacher educators" }\end{array}$ & & \\
\hline Fitzgerald (1998) & (2) $2+$ years & & $\begin{array}{l}\text { (1) Doctoral } \\
\text { students enrolled } \\
\text { in special } \\
\text { education } \\
\text { (2) Preparation in } \\
\text { two or more } \\
\text { certification areas }\end{array}$ & \\
\hline Gholson (1998) & & & & $\begin{array}{l}\mathrm{C} \text { = "Met criteria for the study of expertise in teaching as } \\
\text { established by Berliner (1986): (a) media recognition, } \\
\text { (b) taught at prestigious music education schools, (c) } \\
\text { several former students of this teacher became } \\
\text { world-renowned musicians (Itzhak Perlman, Nadja } \\
\text { Salerno-Sonnenberg) }\end{array}$ \\
\hline
\end{tabular}


TABLE 1 (Continued)

\begin{tabular}{|c|c|c|c|c|}
\hline \multirow[b]{2}{*}{ Study } & \multicolumn{4}{|c|}{ Identification Markers } \\
\hline & Years of Experience & $\begin{array}{c}\text { Social } \\
\text { Recognition/Nomination }\end{array}$ & $\begin{array}{l}\text { Professional/Social } \\
\text { Group Membership }\end{array}$ & $\begin{array}{c}\text { Performance Criteria }(N=\text { Normative, } \\
C=\text { Criterion Based })\end{array}$ \\
\hline Leinhardt (1983) & $\begin{array}{l}\text { (2) "Considerable } \\
\text { experience } \\
\text { teaching" }\end{array}$ & & $\begin{array}{l}\text { (1) Cooperating } \\
\text { teachers }\end{array}$ & $\begin{array}{l}\text { (2) } \mathrm{N}=\text { "Best of these teachers" } \\
\text { (3) Expertise defined in part by: (a) growth of the } \\
\text { students, and (b) skill in bringing students into contact } \\
\text { with appropriate subject matter (high levels of } \\
\text { academic engaged time) }\end{array}$ \\
\hline Leinhardt (1993) & (1) $20+$ years & $\begin{array}{l}\text { (1) "Considered an } \\
\text { expert based on } \\
\text { multiple sources" } \\
\text { including: (a) the } \\
\text { teacher most } \\
\text { frequently cited by } \\
\text { former students, and } \\
\text { (b) strong reputation } \\
\text { with colleagues and } \\
\text { administration }\end{array}$ & & $\begin{array}{l}\text { (1) } \mathrm{N}=\text { Knowledge and love of subject, U.S. history. } \\
\text { Read history and historical analysis voraciously. }\end{array}$ \\
\hline $\begin{array}{l}\text { Leinhardt \& Greeno } \\
\text { (1986) }\end{array}$ & & & & $\begin{array}{l}\text { (1) } \mathrm{N}=\text { Experts identified by reviewing growth scores of } \\
\text { students over a } 5 \text {-year period and selecting the } \\
\text { classrooms that appeared within the highest } 15 \% \text { of } \\
\text { each grade. Classrooms in which the achievement was } \\
\text { in the highest } 20 \% \text { were chosen from among the } \\
\text { high-growth classes. }\end{array}$ \\
\hline $\begin{array}{l}\text { Livingston \& Borko } \\
\quad(1990)\end{array}$ & & $\begin{array}{l}\text { (2) Building principal } \\
\text { and county teacher } \\
\text { center coordinator } \\
\text { (who was also a } \\
\text { faculty member) }\end{array}$ & $\begin{array}{l}\text { (1) Cooperating } \\
\text { teachers }\end{array}$ & $\begin{array}{l}\text { (3) } \mathrm{C}=\text { Expert teachers were identified on the basis of } \\
\text { teaching performance and student achievement by } \\
\text { principal }\end{array}$ \\
\hline Moallem (1998) & $\begin{array}{l}\text { (1) } 7+\text { (with } 3 \text { or } \\
\text { more years in } \\
\text { present context) }\end{array}$ & $\begin{array}{l}\text { (1) "A good reputation } \\
\text { among colleagues and } \\
\text { students" } \\
\text { (1) Excellent regard by } \\
\text { the principal }\end{array}$ & & $\begin{array}{l}\text { (1) } \mathrm{C}=\text { Undergraduate degree in subject matter and } \\
\text { graduate degree in subject matter or education } \\
\text { (1) } \mathrm{C}=\text { No record of serious management or discipline } \\
\text { problems in the classroom } \\
\text { (1) } \mathrm{N}=\text { Knowledge about curriculum and organization } \\
\text { (1) } \mathrm{N}=\text { Evaluation showing competency as a teacher } \\
\text { through classroom observations }\end{array}$ \\
\hline $\begin{array}{l}\text { Peterson \& Comeaux } \\
\text { (1987) }\end{array}$ & $\begin{array}{l}\text { (1) "10 experienced } \\
\text { high school } \\
\text { social studies } \\
\text { teachers" }\end{array}$ & & & \\
\hline Rich (1993) & $\begin{array}{l}\text { (1) } 4+\text { years of } \\
\text { classroom } \\
\text { experience }\end{array}$ & $\begin{array}{l}\text { (2) "Highly regarded by } \\
\text { principals and } \\
\text { colleagues" (Bents \& } \\
\text { Bents, 1990) }\end{array}$ & & $\begin{array}{l}\text { (2) } \mathrm{C}=\text { (a) expressed confidence in their teaching ability, } \\
\text { and (b) facilitated good progress in student achievement }\end{array}$ \\
\hline $\begin{array}{l}\text { Schempp, Manross, } \\
\text { Tan, \& Fincher } \\
\text { (1998) }\end{array}$ & & & $\begin{array}{l}\text { (1) Physical } \\
\text { educators in } \\
\text { public middle } \\
\text { school }\end{array}$ & $\begin{array}{l}\text { (1) } \mathrm{C}=\text { Teachers were "within reasonable proximity to the } \\
\text { investigators" } \\
\text { (1) } \mathrm{C}=\text { Teachers "had to believe that they had expertise in } \\
\text { at least one physical education subject area" }\end{array}$ \\
\hline $\begin{array}{l}\text { Silberstein \& Tamir } \\
\text { (1991) }\end{array}$ & & $\begin{array}{l}\text { (1) Recognized by } \\
\text { principal, supervisor, } \\
\text { parents, and } \\
\text { colleagues }\end{array}$ & & $\begin{array}{l}\text { (2) } \mathrm{N}=\text { (a) Teacher's pedagogical knowledge must be } \\
\text { highly contextual, (b) content domain outweighs other } \\
\text { factors, (c) able to establish routines and classroom } \\
\text { management procedures that allow her to match tasks } \\
\text { with attainments, (d) Schulman's (1986) assertion of } \\
\text { teacher expertise, (e) Berliner's (1986) criteria. } \\
\text { (3) } \mathrm{C}=\text { (a) Students' of teacher used in the case study } \\
\text { consistently performed highly on standardized reading } \\
\text { tests. }\end{array}$ \\
\hline $\begin{array}{l}\text { Solmon \& Lee } \\
\quad(1991)\end{array}$ & (1) "Experiened" & $\begin{array}{l}\text { (1) Recommended by the } \\
\text { district supervisor }\end{array}$ & $\begin{array}{l}\text { (1) Master's degrees } \\
\text { and state } \\
\text { certification in } \\
\text { adapted physical } \\
\text { education }\end{array}$ & $\begin{array}{l}\mathrm{C}=\text { (a) "Teachers with successful evaluations"; (b) } \\
\text { "samples of assessment reports, goals and objectives, } \\
\text { and daily lesson plans written by prospective subjects } \\
\text { were examined for clarity, content, and knowledge } \\
\text { displayed"; and (c) Based on selection factors (a) and } \\
\text { (b), teachers were observed during interactive teaching } \\
\text { for "ability to use class time efficiently, to structure the } \\
\text { environment for learning, and to address individual } \\
\text { students needs" }\end{array}$ \\
\hline
\end{tabular}




\begin{tabular}{|c|c|c|c|c|}
\hline $\begin{array}{l}\text { Standley \& Madsen } \\
\text { (1991) }\end{array}$ & (1) $10+$ years & $\begin{array}{l}\text { (1) Recognition from } \\
\text { colleagues as } \\
\text { outstanding teachers } \\
\text { (formal } \\
\text { commendations and } \\
\text { awards) }\end{array}$ & $\begin{array}{l}\text { (1) Degree in music } \\
\text { education }\end{array}$ & \\
\hline Strahan (1989) & & $\begin{array}{l}\text { (1) Instructional } \\
\text { supervisors were } \\
\text { asked to identify more } \\
\text { and less expert } \\
\text { teachers }\end{array}$ & $\begin{array}{l}\text { (2) All participants } \\
\text { were enrolled in a } \\
\text { teacher education } \\
\text { class ( } 7 \text { with } \\
\text { teaching } \\
\text { experience and } \\
\text { without) }\end{array}$ & \\
\hline $\begin{array}{l}\text { Swanson, O'Connor, } \\
\quad \& \text { Cooney (1990) }\end{array}$ & $\begin{array}{l}\text { (2) "Approximately } \\
\text { ten or more } \\
\text { years" }\end{array}$ & $\begin{array}{l}\text { (2) Designated as } \\
\text { outstanding teachers } \\
\text { by their principals }\end{array}$ & $\begin{array}{l}\text { (1) Mentors for } \\
\text { novice student } \\
\text { teachers } \\
\text { (2) completed a } \\
\text { Master's degree }\end{array}$ & $\begin{array}{l}\text { (2) } \mathrm{C}=\text { Selected as "mentor teacher" within the California } \\
\text { Public School System. }\end{array}$ \\
\hline $\begin{array}{l}\text { Tochon \& Munby } \\
\text { (1993) }\end{array}$ & $\begin{array}{l}\text { (2) } 7+\text { years of } \\
\text { teaching }\end{array}$ & $\begin{array}{l}\text { (1) District } \\
\text { administrators were } \\
\text { asked to recommend } 5 \\
\text { to } 10 \text { language arts } \\
\text { teachers that they } \\
\text { considered to be "the } \\
\text { most experienced at } \\
\text { the junior high level." } \\
\text { They were also asked } \\
\text { to record the criteria } \\
\text { they used to select the } \\
\text { recommended } \\
\text { teachers }\end{array}$ & $\begin{array}{l}\text { (2) M.A. with a } \\
\text { major in } \\
\text { Language Arts } \\
\text { (2) High School } \\
\text { Educational } \\
\text { Studies degree } \\
\text { (teaching degree) } \\
\text { (2) State nomination } \\
\text { with tenure }\end{array}$ & \\
\hline $\begin{array}{l}\text { Vogler, van der } \\
\text { Mars, Cusimano, } \\
\text { \& Darst (1992) }\end{array}$ & & & & $\begin{array}{l}\text { (1) } \mathrm{C}=\text { "Based on criteria suggested in part by Berliner } \\
\text { (1986)" and met at least four of the following five } \\
\text { criteria: (a) selected as state's physical education } \\
\text { teacher of the year; (b) served as school district } \\
\text { physical education master teacher/mentor; (c) served as } \\
\text { state officers in a physical education professional } \\
\text { organization; (d) presented papers at state, regional, and } \\
\text { national conferences/inservices; (e) had exemplary } \\
\text { principal ratings/evaluations }\end{array}$ \\
\hline $\begin{array}{l}\text { Webb, Diana, Luft, } \\
\text { Brooks, \& } \\
\text { Brennan (1997) }\end{array}$ & $\begin{array}{l}\text { (1) } 5+\text { consecutive } \\
\text { years of recent } \\
\text { teaching } \\
\text { experience }\end{array}$ & $\begin{array}{l}\text { (1) Experts were } \\
\text { identified by } \\
\text { principals, assistant } \\
\text { principals, or staff } \\
\text { development } \\
\text { personnel in } \\
\text { consultation with the } \\
\text { first and second } \\
\text { authors. }\end{array}$ & & $\begin{array}{l}\text { (1) } \mathrm{C}=\text { Berliner's }(1986,1988) \text { criteria for teacher } \\
\text { expertise level were used: (a) teachers demonstrated an } \\
\text { effortless, fluid performance of the highest quality; and } \\
\text { (b) often confronted and solved problems in a } \\
\text { deliberate and analytic fashion appropriate to those } \\
\text { problems } \\
\text { (2) } \mathrm{N}=\text { Candidates were screened again by first and } \\
\text { second authors to select } 10 \text { teachers who best matched } \\
\text { the criteria used }\end{array}$ \\
\hline Westerman (1991) & & $\begin{array}{l}\text { (2) "Selected by } \\
\text { administrators and by } \\
\text { university personnel } \\
\text { skilled in } \\
\text { observational methods } \\
\text {..." }\end{array}$ & & $\begin{array}{l}\text { (1) } \mathrm{N} \text { = Expert observers examined teachers for the } \\
\text { following: (a) integrated curriculum, (b) able to } \\
\text { promote reflection in student teachers, (c) willing to } \\
\text { spend time developing a problem-solving orientation } \\
\text { toward teaching, (d) consistently used strategies they } \\
\text { wanted student teachers to follow, and (e) followed } \\
\text { university's instructional philosophy }\end{array}$ \\
\hline
\end{tabular}

ria emerged: (a) years of experience, (b) social recognition/nomination, (c) professional/social group membership, and (d) other. Following discussion among the researchers, the "Other" category was further refined to "Performance" and included the differentiation of "Normative" and "Criterion-Based" performance criteria.
"Normative" criteria required a comparison to other potential participants in that these expert teachers were chosen on the basis of how well they performed on a specific task as compared to peers or novices. Examples of this criteria included "talkative" teachers chosen by principals for participating in stimulated recall activities (e.g., Allen \& 
Casbergue, 1997) and direct observation of classroom teaching by independent experts (e.g., Bromme \& Steinbring, 1994).

Another type of performance-based criteria were those that were "criterion-based" in that the teacher's performance was rated against a predetermined standard. Examples included teachers who received the highest possible rating by three different student teacher supervisors on given criteria (e.g., Copeland, Birmingham, DeMeulle, D'Emidio-Caston, \& Natal, 1994) and teaching performance appraisals and measures of student achievement (Livingston \& Borko, 1990).

In the process of examining these studies, it was evident that the order in which researchers used these criteria varied. This variation resulted in the differential screening of the teachers that were chosen as experts in a given study. In order to reflect the variability of the order in which these selection criteria were applied, we noted the sequence in which these criteria were mentioned in the article. In some cases, it appeared that these criteria were applied concurrently and in many cases this order was unclear. In these cases, we ranked all the criteria as concurrently applied.

\section{MARKER VARIABLES USED TO IDENTIFY TEACHER EXPERTISE}

A summary chart of marker variables used to identify teacher expertise by researchers in 27 selected studies is presented in Table 1. Summarized information on the selection criteria used in each of the studies is presented under one or more of the four marker categories: (a) years of experience, (b) social recognition or nomination, (c) professional or social group membership, and (d) performance-based criteria. The order in which these markers were used in selecting the expert teacher sample was also identified for each study.

In 16 of the 27 studies presented in Table 1, "years of experience" was a marker used to select the teachers in this study. In 13 of these same studies, the specific number of years of experience was indicated, and this number ranged from 2 to 20 years, with most studies requiring that the number of years of experience be between 5 and 10 years. Two studies constrained the type of experience in which the teaching experience took place. Moallem (1998) required 7 or more years of teaching experience and further required that 3 of these years be in the same instructional context. Webb, Diana, Luft, Brooks, and Brennan (1997) stipulated that the required 5 or more years of teaching experience be consecutive. Three studies used "extensive experience in elementary teaching" (Copeland et al., 1994); "considerable teaching experience" (Leinhardt, 1983); and "experienced high school teachers" (Peterson \& Comeaux, 1987) to refer to amount of experience. In most cases, the number of years of teaching experience was information gathered after these teachers were selected as part of the sample, rather than having been used as a selection criteria. In some of these same studies, years of experience was not directly used as a selection criteria but the experience of the participants was suggested in the description of the sample.

Social recognition or nomination was reported as having been used in 17 of the 27 studies. Of the 17 studies using social recognition or nomination as an identification criterion, 15 requested expert teacher nominations from school administrators with a principal's nomination as most common. Numerous studies sought nominations from a number of different administrators throughout a district; however, it is not clear whether these different administrators provided confirming input or enabled the researchers to cast a wider net to identify expert teachers. In addition to administrators, nominations from other groups was also sought to identify expert teachers. These groups included other teachers, university personnel, students, and parents. The numbers of studies considering nominations from nonadministrative school staff was relatively small, for example, two studies cited students and/or parents, three considered input from university personnel, and four studies reflected on input from teacher colleagues. Approximately one-third of the studies (6) appeared to use nominations from multiple constituencies to confirm the identification of experts. For 16 of the 17 studies using social recognition, this selection criterion was used concurrently with other markers.

A third variable used for selection was that of professional or social group membership. Thirteen of the 27 studies used some type of group membership indicator, usually teacher certification, in order to select the sample. Other studies used membership in an educational organization, status as a cooperating or mentor teacher, having tenure, holding an advanced university degree, "taught at a prestigious music school," or "enrolled in a teacher education class" as criteria. However, the criterion of group membership was not used as a sole selection criterion in any of the studies reviewed.

In 16 of the 27 studies, a performance criterion also was used as a criterion in selecting a sample. The studies used either normative ( 5 studies), criterion-based (9 studies), or a mixture of the two ( 2 studies). In the studies that used a normative measure, teachers were compared to their peers using: (a) general comparisons such as "talkative" or "practical and theoretical knowledge about curriculum and organization;" (b) researcher observation and screening, including multiple ratings by the researchers; and (c) general criteria, such as "based on Berliner's (1986) criteria." In studies that used criterion-based measures, teachers were selected based on rating scales such as "the North Carolina Teacher Appraisal Instrument," and "independently rated as 'superior teacher' by three different student teaching supervisors."

Of all 27 articles examined, only Swanson, O'Connor, and Cooney (1990) and Solmon and Lee (1991) selected expert teachers using all four types of identification markers. Both of these studies included a criterion-based marker, rather than a normative marker, as part of their selection process. 
Of the 27 studies reviewed, 21 used multiple indicators across marker categories to select expert teachers. In these 21 studies, 15 used gating screening procedures. The first gate in the selection process varied across studies, for example, years of experience (3 studies), social recognition (6 studies), professional/social group membership (5 studies), and performance criteria ( 1 study). It is interesting to note that of the 21 studies using multiple indicators across marker categories, 6 appeared to use the indicators simultaneously, not a serial gating procedure.

\section{DISCUSSION}

Our review of published research articles that identified expert teachers revealed significant variability in the selection criteria used by investigators to identify these teachers. While we limited our literature review exclusively to those articles that built upon the cognitive theory of expertise and that explicitly identified their sample of teachers as "expert," there remained significant differences in how researchers operationalized their selection of expert teachers. As noted by Bell and Hertz (1976) and Light and Pillemer (1984), variability in operational definitions of variables under investigation severely limits researchers' ability to generalize about the population from a given sample. The teachers in these studies varied in years of experience, type of certification, and nomination criteria used, thus limiting the extent to which results from these studies can be generalized. Messick (1989) has noted that there is concern with the generalizability of such constructs across different population groups, contexts, and tasks. The lack of consistency in both the use of the domain observables and the decision rules or specific indicators used within the domain also limits generalizability; for example, variability in the number of years of experience used to select teachers.

Expertise in teaching is a complex construct (Kennedy, 1987) that has been associated with instructional effectiveness, teaching experience, what and how teachers think, and how teachers behave (e.g., Lampert \& Clark, 1990; Siedentop \& Eldar, 1989; Sternberg \& Horvath, 1995). However, Cook and Campbell (1979) have noted that a threat to construct validity is construct underrepresentation, which results when measures of the construct fail to include important dimensions of the construct. While over three-fourths of the studies in our paper used multiple indicators to select expert teachers, less than half used more than two of the four indicators. Only two of the articles, Swanson et al. (1990) and Solmon and Lee (1991) used all four domains. As a result, many of these studies with expert teachers may have failed to include important dimensions of the construct of expertise when identifying these teachers.

The identification methodologies used in these studies can be conceptualized as a test that contains varying domains of the latent construct expertise. As such, our review suggests that the field has engaged in a haphazard multimethod (including identifying domains of experience, social recognition, professional/social group membership, and performance criteria) multitrait (expert, novice) analysis of the construct of expertise (cf. Campbell \& Fiske, 1959). Unfortunately, the sample selection methodologies in our literature review reveal unsystematic variation both within and across identification domains. Systematic study of teacher expertise using a consistently defined set of selection criteria is needed to allow a more precise and reliable description of the cognition, behavior, and impact of these teachers.

\section{Proposed Guidelines in Selecting Expertise}

Reflecting on expert teacher selection criteria reviewed in this study, as well as on the selection criteria that has been used to select participants in other domains of expertise, we suggest that researchers in this area consider the following results as a guide in selecting samples of expert teachers.

Teaching experience. Researchers in the group of studies who used teaching experience to select their sample used three to five years of experience as a criteria. It seems clear that experience is a necessary, although not sufficient condition in the selection of expert teachers. Assuming that teachers work 7 hours per day for approximately 185 days per year, a 5-year period reflects approximately 6,500 hours of "practice." This level of practice is consistent with that used in other fields as the minimum level of practice required to establish expertise (see Ericsson et al., 1993). It is also necessary to identify the type of teaching experience needed to foster the development of expertise. As suggested by Berliner (1994), we cannot assume that expert teachers are experts across all content domains, across all age groups, or across diverse characteristics of students-expertise has consistently been found to be domain bound and context bound. Therefore, we propose that the criteria of teaching experience should include consideration of the context as well as the time of the experience. It should be considered that at least three of a teacher's most recent years of experience be in the same instructional context in which the teacher is being identified as an expert.

Our review of the teacher expertise research also suggested that investigators did not address a critical component associated with experiences of experts, that is, opportunities for corrective feedback (Ericsson et al., 1993). Experts in various fields of endeavor have often been given informative feedback on their performance which, in turn, has resulted in opportunities for them to revise cognitions and improve behaviors. Experience, without feedback on how to improve, is unlikely to lead to high levels of functioning. No study reviewed for this article provided information on the professional development afforded by corrective feedback opportunities that teachers may have received during their years of teaching experience. 
Social nomination-recognition. Social nomination and recognition is also a necessary condition for determining expertise (Agnew et al., 1997). We suggest that a confirmatory nomination-recognition process be used whereby two or more different constituencies independently recognize a teacher's expertise. This recognition might be based primarily on evidence of teaching effectiveness by supervisors, teaching colleagues, or researchers. This recommendation reflects the social context of the identification of expertise in that expertise; teacher expertise is identified by others who recognize the extraordinary skills and student outcomes of the nominated teacher.

Acknowledging that expertise is, in part, a social designation, implies that different constituencies may apply widely divergent criterion to identify expertise, and that these criteria may vary greatly in terms of their reliability and validity (Agnew et al., 1997). Reliability of a social nomination or recognition indicator of teaching expertise is directly related to the specific criteria that these constituencies use to derive their judgment. The closer these criteria are to scientifically derived indicators of teaching effectiveness the more accurate the social nomination process, for example, teacher impact on student learning. Teacher expertise nominations should be based on information that reflects upon specific research-derived indicators of teaching effectiveness (see Berliner, 1994; Clark \& Peterson, 1986). A related methodological recommendation concerns the use of procedures to enhance the validity of verbal report of social nomination information (see Ericsson \& Simon, 1980). Validity of the nomination will be greater if it is based on information that is current and reflects teaching performance within that instructional context.

Our analysis of the research methodologies reflects a focus on a personally constructed and socially selected identification process for expertise in contrast to a scientifically derived, empirically supported nomination process (see Agnew et al., 1997). The consequence of this current practice for expertise identification may result in a number of false positives, thus confounding results on teaching expertise obtained in some studies.

Teaching performance. Additional confirmatory performance criteria are also recommended for identification of teacher expertise. Many of the studies did consider some teaching performance criteria, for example, student achievement. However, there was great variability in these performance domains, for example, teaching at three different grade levels and rated highly by student teaching supervisors (Copeland et al., 1994), knowledge and love of subject (Leinhardt, 1993), used Berliner's (1986) criteria (Webb et al., 1997), and student achievement growth over a multi-year period (Leinhardt \& Greeno, 1986). A further complicating aspect of using performance criteria as an identification marker again concerns the dramatic differences in instructional contexts. Establishing standards for student perfor- mance to identify expert teachers is technically challenging in light of the variability of student populations and their associated instructional contexts - which can range from functional life skills curricula for students with severe disabilities to advance placement calculus content for college-bound high school students. Even within a specified student population, there is significant variability in possible student outcomes, for example, high stakes testing performance, transfer of knowledge and skills to applied settings, social outcomes, self-regulated learning, and creative and analytic thinking (Sternberg, 2003). Although there may be a great deal of diversity in the nature of the student outcome, documented impact on student performance should be the sine qua non of teaching expertise. However, it is likely that identified expert teachers will vary in their ability to effectively promote student performance in all domains. The selection of student performance in targeted domains of interest will have a significant impact on who would be considered a highly effective teacher.

Professional and group membership. Our review also revealed limited reliance on professional and group membership as a selection criteria, certification was not always used as a primary indicator of expertise. Furthermore, there was little consensus in researchers' selection of professional and group membership criteria and these criteria ranged from appropriate teaching certification to doctoral degrees. In contrast to other fields such as medicine (Patel et al., 1996), appropriate teacher certification and degrees may be seen as necessary but not sufficient as an isolated criterion for selecting expert teachers.

Related to certification and expert group membership, there is consistent support for the importance of teachers' subject matter knowledge on student performance (Allen, 2003); however, there is limited information on the impact of major and graduate degrees in the subject on student performance. There is also evidence that content knowledge and teacher's knowledge and skills in classroom management, student assessment, and curriculum development all contribute to teachers' effectiveness (Allen, 2003). Shulman (1987) similarly proposes that teaching expertise is grounded in teacher content, pedagogical, and curriculum knowledge. Drawing on this literature, the National Board for Professional Teaching Standards has implemented a system of advanced teacher certification (Bond et al., 2000). Bond et al. (2000) reported that National Board Certified teachers evidenced characteristics consistent with the teacher expertise literature and there was some limited support for improved student performance when compared to non-National Board Certified teachers. If certification standards and licensing requirements were directly tied to critical domains of teacher knowledge and skill, certification may be seen as a more direct indicator of expertise.

It is interesting to note that according to the No Child Left Behind Act, teachers are "highly qualified" when they meet the 
following conditions: (a) a college degree; (b) full certification or licensure; and (c) demonstrated content knowledge as evidenced by the following: new elementary teachers passing a state literacy and numeracy test, new secondary teachers passing a subject area test or having completed a relevant college major; or veteran teachers demonstrating content knowledge through state test, college degrees, or some other state designed process which may include experience. While these conditions reflect elements of the proposed markers to identify expert teachers, it is noteworthy that there is little attention given to documented evidence of these teachers' impact on student performance and social recognition or on the use as indicators of teacher expertise. Moreover, novice teachers who pass state literacy tests and hold certifications can be judged as "highly qualified" despite having limited experience in the classroom-despite evidence that experience is a necessary precursor to teacher effectiveness.

\section{CONCLUSION}

In sum, there was substantial variability in how researchers identified expert teachers, although some researchers did use consistent criteria across their own studies. The idiosyncratic nature of researchers' identification of expert teachers suggests that expertise, like beauty, may be in the eye of the beholder. Unfortunately, it also suggests that the generalizability of this research may be limited by a lack of consensus on how expert teachers are selected. The accurate identification of a teacher as "expert" is important as it assumes that underlying cognitive qualities exist and because it distinguishes the cognitive processes of these teachers from those of novices. Research also suggests that expert teachers possess more knowledge about classroom practice than do novices and that this domain knowledge is organized differently than that of novices (Borko \& Livingston, 1989; Sabers, Cushing, \& Berliner, 1991). In addition, expert teachers seem to make judgments about students differently (Leinhardt, 1983; Stader, Colyar, \& Berliner, 1990), and pay attention to specific information about students when planning and implementing their lessons (Carter \& Doyle, 1987; Strahan, 1989). Thus, the construct of teacher expertise is a powerful one in that it links the identifying markers of an expert teacher with underlying cognitive traits, as well as to observable outcome measures such as student achievement. The promise of research on teacher expertise is that it enhances our general understanding of quality teachers that, in turn, may lead to the design of effective teacher preparation activities.

The impact of this research, however, is dependent upon the consensual agreement among researchers on what constitutes an expert teacher. The identification of expert teachers is clearly influenced by the background of those who are determining the criteria to be used as "expert." For example, researchers who value the argument that pedagogical content knowledge is the primary knowledge that teachers must have in order to teach a particular subject area may use a criteria that includes some sort of measure of the teacher's content knowledge. This survey of what criteria are used to identify expertise in teaching thus gives us a reflection of what characteristics teacher researchers believe is most salient in effective teachers.

We propose that researchers consider a multigated procedure for selecting expert teachers. Such an approach would reduce the likelihood of false positives in the selection of expert teachers, as well as lead to the establishment of both a Level I and Level II definition of expertise (cf. Agnew et al., 1997). Reflecting on the selection criteria used in past investigations of teacher expertise that we have detailed in this article as well as the criteria used by researchers in other domains of expertise, we suggest that there is a need for researchers to more consistently select their samples of expert teachers. Any rubric developed to identify quality teachers will need to attend to the unique contextual demands of the instructional setting. These factors will include substantial subject area and pedagogical expertise, as well as in-depth knowledge of students (Stough \& Palmer, 2003). The proposed marker variables represent broad domains upon which the construct of expertise may be examined (Nunnally \& Bernstein, 1994). Therefore, examination of teacher expertise in specific instructional settings and content domains will require consideration of the unique teaching knowledge, skills, and outcomes. Most conservatively, we suggest that researchers consider the use of the following as guidelines, which includes elements of all four categories of selection that we have described in this article, for selecting expert teachers. Specifically, we are proposing the following two-gate identification procedure:

\section{First Gate: Screening}

Teachers should have: (a) three to five years of experience in a specific teaching content area and with a particular population of students, and (b) teacher knowledge as reflected in relevant certification and degrees that correspond to the field in which these teachers are currently teaching.

\section{Second Gate: Performance Indicators}

Recognition as an exemplary teacher by: (a) multiple constituencies, for example, fellow teachers, researchers, administrators, teacher educators, based on recent and relevant indicators of teaching effectiveness to include teacher knowledge and skills, and (b) should be confirmed with documented evidence of teacher impact on student performance.

Although this recommended identification procedure may result in increased numbers of false negatives in the identification of teacher expertise and undoubtedly will increase the difficulty and cost with which researchers select expert teachers, 
it also increases the likelihood that descriptions of expert teachers will be more consistent, verifiable, and generalizable.

\section{REFERENCES}

Agnew, N. M., Ford, K. M., \& Hayes, P. J. (1997). Expertise in context: Personally constructed, socially selected, and reality-relevant? In P. J. Feltovich, K. M. Ford, \& R. R. Hoffman (Eds.), Expertise in context (pp. 219-244). Cambridge, MA: MIT Press.

Alexander, P. (2003). Can we get there from here? Educational Researcher, $32(8), 3-4$.

Allen, M. (2003). Eight questions on teacher preparation. Denver, CO: Education Commission of the States (ECS).

Allen, R. M., \& Casbergue, R. M. (1997). Evolution of novice through expert teachers' recall: Implications for effective reflection on practice. Teaching and Teacher Education, 13, 741-755.

American Council on Education. (1999). To touch the future; transforming the way teachers are taught. Washington, DC: Author.

Bartelheim, F. J., \& Evans, S. (1993). The presence of reflective-practice indicators in special education resource teachers' instructional decision making. The Journal of Special Education, 27, 338-347.

Bell, R. Q., \& Hertz, T. W. (1976). Toward more comparability and generalizability of developmental research. Child Development, 47, 6-13.

Berliner, D. C. (1986). In pursuit of the expert pedagogue. Educational Researcher, 15, 5-13.

Berliner, D. C. (1988, February). The development of expertise in pedagogy. Paper presented at the meeting of the American Association of Colleges for Teacher Education, New Orleans, LA.

Berliner, D. C. (1994). Expertise: The wonder of exemplary performances. In J. N. Mangieri \& C. C. Block (Eds.), Creating powerful thinking in teachers and students (pp. 161-186). Fort Worth, TX: Holt, Rinehart \& Winston.

Bond, L., Smith, T., Baker, W. K., \& Hattie, J. A. (2000). The certification system of the National Board for Professional Teaching Standards: A construct and consequential validity study. Greenboro: University of North Carolina, Center for Education Research and Evaluation.

Borko, H., \& Livingston, C. (1989). Cognition and improvisation: Differences in mathematics instruction by expert and novice teachers. American Educational Research Journal, 26, 473-498.

Bromme, R., \& Steinbring, H. (1994). Interactive development of subject matter in the mathematics classroom. Educational Studies in Mathematics, 27, 217-248.

Brophy, J., \& Good, T. (1986). Teacher behavior and student achievement. In M. Wittrock (Ed.), Handbook of research on teaching (pp. 340-270). New York: Macmillan.

Bullough, R. V., Jr., \& Baughman, K. (1995). Changing contexts and expertise in teaching: First-year teacher after seven years. Teaching and Teacher Education, 11(5), 461-477.

Calderhead, J. (1996). Teachers: Beliefs and knowledge. In D. Berliner \& R. Calfee (Eds.), Handbook of educational psychology (pp. 709-725). New York: Macmillan.

Campbell, D. T., \& Fiske, D. W. (1959). Convergent and discriminant validation by the multitrait-multimethod matrix. Psychological Bulletin, 56, 81-105.

Carter, K., Sabers, D., Cushing, K., Pinnegar, S., \& Berliner, D. C. (1987). Processing and using information about students: A study of expert, novice, and postulant teachers. Teaching and Teacher Education, 3, 147-157.

Charness, N., Krampe, R., \& Mayr, U. (1996). The role of practice and coaching in entrepreneurial skill domains: An international comparison of life-span chess skill acquisition. In K. A. Ericsson (Ed.), The road to excellence: The acquisition of expert performance in the arts, sciences, sports, and games (pp. 51-80). Hillsdale, NJ: Lawrence Erlbaum Associates, Inc.

Chi, M. T. H., Feltovich, P. J., \& Glaser, R. (1981). Categorization and representation of physics knowledge by experts and novices. Cognitive Science, 5, 121-152.
Clark, C. M., \& Peterson, P. L. (1986). Teachers' thought processes. In M. C. Wittrock (Ed.), Handbook of research on teaching (pp. 255-296). New York: Macmillan.

Cleary, M. J., \& Groer, S. (1994). Inflight decisions of expert and novice health teachers. Journal of School Health, 64(3), 110-114.

Cook, T. D., \& Campbell, D. T. (1979). Quasi-experimentation: Design \& analysis issues for field settings. Chicago: Rand McNally.

Copeland, W. D., Birmingham, C., DeMeulle, L., D'Emidio-Caston, J., \& Natal, D. (1994). Making meaning in classrooms: An investigation of cognitive processes in aspiring teachers, experienced teachers, and their peers. American Educational Research Journal, 31, 166-196.

Doyle, W. (1986). Classroom organization and management. In M. Wittrock (Ed.), Handbook of research on teaching (pp. 392-425). New York: Macmillan.

Dwyer, C., \& Stufflebeam, D. (1996). Teacher evaluation. In D. Berliner \& R. Calfee (Eds.), Handbook of educational psychology (pp. 765-786). New York: Macmillan.

Education Trust. (2003). Telling the whole truth (or not) about highly qualified teachers. Washington, DC: The Education Trust.

Elo, A. (1986). The rating of chessplayers: Past and present. New York: Arco Publishing.

Ericsson, K. A. (1996). The acquisition of expert performance: An introduction to some of the issues. In K. A. Ericsson (Ed.), The road to excellence: The acquisition of expert performance in the arts, sciences, sports, and games (pp. 1-50). Hillsdale, NJ: Lawrence Erlbaum Associates, Inc.

Ericsson, K. A., Krampe, R. T., \& Tesch-Romer, C. (1993). The role of deliberate practice in the acquisition of expert performance. Psychological Review, 100(3), 363-406.

Ericsson, K. A., \& Simon, H. A. (1980). Verbal reports as data. Psychological Review, 87(3), 215-251.

Ethell, R. G., \& McMeniman, M. M. (2000). Unlocking the knowledge in action of an expert practitioner. Journal of Teacher Education, 51(2), 87-101.

Fitzgerald, G. E. (1998). Expert and novice performance in a hypermedia learning environment for classroom observation skills: The impact of prior teaching experience. Journal of Educational Computing Research, 19(2), 115-131.

Gersten, R., Fuchs, L. S., Williams, J. P., \& Baker, S. (2001). Teaching reading comprehension strategies to students with learning disabilities: A review of the research. Review of Educational Research, 71, 279-320.

Gholson, S. A. (1998). Proximal positioning: A strategy of practice in violin pedagogy. Journal of Research Methodology Evaluation, 46(4), 535-545.

Glaser, R., \& Chi, M. T. H. (1988). Overview. In M. T. H. Chi, R. Glaser, \& M. J. Farr (Eds.), The nature of expertise (pp. 15-27). Hillsdale, NJ: Lawrence Erlbaum Associates, Inc.

Housner, L. D., \& Griffey, D. (1985). Teacher cognition: Differences in planning and interactive decision making between experienced and inexperienced teachers. Research Quarterly for Exercise and Sport, 56(1), $45-53$.

Kennedy, M. M. (1987). Inexact sciences: Professional education and the development of expertise. In E. Z. Rothkopf (Ed.), Review of research in education (pp. 133-167). Washington, DC: American Educational Research Association.

LaFrance, M. (1997). Metaphors for expertise: How knowledge engineers picture human expertise. In P. J. Feltovich, K. M. Ford, \& R. R. Hoffman (Eds.), Expertise in context. Cambridge, MA: MIT Press.

Lampert, M., \& Clark, C. M. (1990). Expert knowledge and expert thinking in teaching: A response to Floden and Klinzing. Educational Research, 19(5), 21-23.

Leinhardt, G. (1983). Novice and expert knowledge of individual student's achievement. Educational Psychologist, 18, 165-179.

Leinhardt, G. (1993). Weaving instructional explanations in history. British Journal of Educational Psychology, 63, 46-74.

Leinhardt, G., \& Greeno, J. G. (1986). The cognitive skill of teaching. Journal of Educational Psychology, 78, 75-95.

Light R. J., \& Pillemer, D. B. (1984). Summing up: The science of reviewing research. Cambridge, MA: Harvard University Press. 
Livingston, C., \& Borko, H. (1989). Expert and novice differences in teaching: A cognitive analysis and implications for teacher education. Journal of Teacher Education, 40, 36-42.

Livingston, C., \& Borko, H. (1990). High school mathematics review lessons: Expert-novice distinctions. Journal for Research in Mathematics Education, 21(5), 372-387.

Messick, S. (1989). Validity. In R. L. Linn (Ed.), Educational measurement (pp. 13-103). New York: Macmillan.

Moallem, M. (1998). An expert teacher's thinking and teaching and instructional design models and principles: An ethnographic study. Educational Technology Research and Development, 46, 37-64.

National Commission on Teaching and America's Future. (2003) No dream denied: A pledge to America's children. Washington, DC: National Commission on Teaching and America's Future.

No Child Left Behind Act of 2001, Pub. L. No. 107-110 (2002).

Nunnally, J. C., \& Bernstein, I. H. (1994). Psychometric theory. New York: McGraw-Hill.

Patel, V. L., Kaufman, D. R., \& Magder, S. A. (1996). The acquisition of medical expertise in complex dynamic environments. In K. A. Ericsson (Ed.), The road to excellence: The acquisition of expert performance in the arts, sciences, sports, and games (pp. 127-166). Hillsdale, NJ: Lawrence Erlbaum Associates, Inc.

Peterson, P. L., \& Comeaux, M. A. (1987). Teachers' schemata for classroom events: The mental scaffolding of teachers' thinking during classroom instruction. Teaching \& Teacher Education, 3(4), 319-331.

Rich, Y. (1993). Stability and change in teacher expertise. Teacher \& Teacher Education, 9(2), 137-146.

Sabers, D. S., Cushing, K. S., \& Berliner, D. C. (1991). Differences among teachers in a task characterized by simultaneity, multidimensionality, and immediacy. American Educational Research Journal, 28(1) 63-88.

Schempp, P. G., Manross, D., Tan, S. K. S., \& Fincher, M. D. (1998). Subject expertise and teachers' knowledge. Journal of Teaching in Physical Education, 17, 342-356.

Shulman, L. S. (1987). Knowledge and teaching: Foundations of the new reform. Harvard Educational Review, 57(1), 1>@150>22.

Siedentop, D., \& Eldar, E. (1989). Expertise, experience, and effectiveness. Journal of Teaching in Physical Education, 8, 254-260.

Silberstein, M., \& Tamir, P. (1991). The expert case study model: An alternative approach to the development of teacher education modules. Journal of Education for Teaching, 17(2), 165-179.

Simon, H. A., \& Chase, W. G. (1973). Skill in chess. American Scientist, 61, 394-403.

Sloboda, J. A. (1996). The acquisition of musical performance expertise: Deconstructing the "talent" account of individual differences in musical expressivity. In K. A. Ericsson (Ed.), The road to excellence: The acquisition of expert performance in the arts, sciences, sports, and games (pp. 107-126). Hillsdale, NJ: Lawrence Erlbaum Associates, Inc.
Solmon, M. A., \& Lee, A. M. (1991). A contrast of planning behaviors between expert and novice adapted physical education teachers. Adapted Physical Activity Quarterly, 8, 115-127.

Stader, E., Colyar, T., \& Berliner, D. C. (1990, April). Expert and novice teachers' ability to judge student understanding. Paper presented at the meeting of the American Educational Research Association, Boston, MA.

Standley, J. M., \& Madsen, C. K. (1991). An observation procedure to differentiate teaching experience and expertise in music education. Journal of Research in Music Education, 39(1), 5-11.

Starkes, J. L., Deakin, J. M., Allard, F., Hodges, N. J., \& Hayes, A. (1996). Deliberate practice in sports: What is it anyway? In K. A. Ericsson (Ed.), The road to excellence: The acquisition of expert performance in the arts, sciences, sports, and games (pp. 81-106). Hillsdale, NJ: Lawrence Erlbaum Associates, Inc.

Sternberg, R. J. (1998). Abilities are forms of developing expertise. Educational Researcher, 27(3), 11-20.

Sternberg, R. J. (2003). What is an "expert student?" Educational Researcher, 32(8), 5-9.

Sternberg, R. J., \& Horvath, J. A. (1995). A prototype view of expert teaching. Educational Researcher, 24(6), 9-17.

Stough, L. M., \& Palmer, D. J. (2003). Special thinking in special settings: A qualitative study of expert special educators. The Journal of Special Education, 36(4), 206-222.

Strahan, D. B. (1989). How experienced and novice teachers frame their views of instruction: An analysis of semantic ordered trees. Teaching \& Teacher Education, 5, 53-67.

Swanson, H. L., O'Connor, J. E., \& Cooney, J. B. (1990). An information processing analysis of expert and novice teachers' problem solving. American Educational Research Journal, 27(3), 533-556.

Tochon, F., \& Munby, H. (1993). Novice and expert teachers' time epistemology: A wave function from didactics to pedagogy. Teacher \& Teacher Education, 9(2), 205-218.

Vogler, E. W., van der Mars, H., Cusimano, B. E., \& Darst, P. (1992). Experience, expertise, and teaching effectiveness with mainstreamed and nondisabled children in physical education. Adapted Physical Activity Quarterly, 9, 316-329.

Webb, J. M., Diana, E. M., Luft, P., Brooks, E. W., \& Brennan, E. L. (1997). Influence of pedagogical expertise and feedback on assessing student comprehension from nonverbal behavior. Journal of Educational Research, 91, 89-97.

Westerman, D. A. (1991). Expert and novice teacher decision making. Journal of Teacher Education, 42(4), 292-305.

Winner, E. (1996). The rage to master: The decisive role of talent in the visual arts. In K. A. Ericsson (Ed.), The road to excellence: The acquisition of expert performance in the arts, sciences, sports, and games (pp. 271-302). Hillsdale, NJ: Lawrence Erlbaum Associates, Inc. 
Copyright of Educational Psychologist is the property of Lawrence Erlbaum Associates and its content may not be copied or emailed to multiple sites or posted to a listserv without the copyright holder's express written permission. However, users may print, download, or email articles for individual use. 
Copyright of Educational Psychologist is the property of Lawrence Erlbaum Associates and its content may not be copied or emailed to multiple sites or posted to a listserv without the copyright holder's express written permission. However, users may print, download, or email articles for individual use. 